\title{
Intracanal Medicaments - A Review Of Literature
}

Research Article

Iffat Nasim $^{1 *}$, Srujana Hemmanur ${ }^{2}$

${ }^{1}$ Professor and Head, Department of Conservative Dentistry and Endodontics, Saveetha Dental College and Hospital, Saveetha Institute of Medical and Technical Sciences, Saveetha University, Chennai, India.

${ }^{2}$ Department of Conservative Dentistry and Endodontics, Saveetha Dental College and Hospital, Saveetha Institute of Medical and Technical Sciences, Saveetha University, Chennai, India.

\section{Abstract}

The presence of bacteria in teeth with apical periodontitis is a well established fact. The success of endodontic treatment depends on minimising the microbial load and preventing it from getting recolonised with in the canal system. The disinfection protocol depends on the ample usage of irrigants and intracanal medicaments. Intracanal medicaments tend to eliminate bacteria in the inter-appointment phases.

Hence, it is imperative for clinicians to understand the factors that affect the action of an intracanal medicament and factors that help in choosing the right one depending on the case.

The current review was performed to check for various intracanal medicaments available and their effect.

Keywords: Endodontic Therapy; Medicament; Microbial; Natural; Pain.

\section{Introduction}

The contribution of bacteria causing infection of the root canal system has been proven over time again and again. The periapical inflammation is initiated and maintained by bacteria and their byproducts [1]. Various species including aerobic, facultative anaerobes and anaerobic bacteria are found in the root canals and periapical tissues. Anaerobic bacteria dominate the bacterial flora in root canal infections and several different species are commonly found. Periapical destruction with vital pulp is a rare occurrence [2].

The inflammation and/or infection of the pulpal and/or periapical tissues cannot be left untreated [3]. Based on diagnosis, endodontic therapy or root canal treatment may become the treatment of choice for such an infection. The aim of endodontic therapy is to eliminate bacteria and bacterial by-products and to avert re-infection [4]. Even after following a proper cleaning and shaping protocol, it is important to understand that not all of the bacterial niches get cleared off. Bacteria may multiply exponentially in roots left with no dressing or filling inter-appointment [5]. Interappointment bacterial growth can be reduced by placing an appropriate intracanal medicament dressing [6]. Studies have indicated the predominance of strict anaerobes and facultative anaerobes in the root canal systems. As pulp becomes necrotic an increase in strict anaerobic Gram-negative and Gram-positive species such as E. Faecalis occurs at the expense of facultative anaerobic species [7].

Intracanal medication destroys residual microorganisms, toxins and residual bacteria that are failed from removal via chemomechanical preparation [5]. The aim of chemomechanical preparation is to remove microbes and the byproducts, the complexity of the root canal system makes it difficult to render it completely bacteria-free. Also, studies have reported that the bacteria exist in the form of thick microbial biofilms and invade deep in to den-

*Corresponding Author:

Iffat Nasim,

Professor and Head, Department of Conservative Dentistry and Endodontics Saveetha Dental College and Hospital, Saveetha Institute of Medical and Technical Sciences, Saveetha University, Chennai, India.

Tel: +919940063567

Email Id: iffatnasim@saveetha.com

Received: April 28, 2021

Accepted: May 28, 2021

Published: May 30, 2021

Citation: Iffat Nasim, Srujana Hemmanur. Intracanal Medicaments - A Review Of Literature. Int J Dentistry Oral Sci. 2021;08(05):2643-2648. doi: http://dx.doi.org/10.19070/2377-8075-21000517

Copyright: Iffat Nasim ${ }^{\circ} 2021$. This is an open-access article distributed under the terms of the Creative Commons Attribution License, which permits unrestricted use, distribution and reproduction in any medium, provided the original author and source are credited. 
tinal tubules and isthmus $[8,9]$. Intracanal medicaments prevent microbial multiplication and recolonisation, kill residual bacteria and prevent reinfection [10].

The bacterial species commonly associated with primary root canal infections belong to the genera Bacteriodes, Fusobacterium, Prevotella, Porphyromonas, Treponema, Peptostreptococcus, Eubacterium, Actinomyces and Streptococcus [11]. Actinomyces species is found in approximately 10 to $15 \%$ of primary root canal infections. Actinomyces gerencseriae and Actinomyces israelli are the most prevalent species in periradicular abscess cases. Streptococcus intermedius, Streptococcus constellatus, Streptococcus anginosus form a part of the normal microbiota of oral cavity, gastrointestinal tract and genito-urinary tract are associated with purulent infections. Facultative anaerobes are commonly associated with infected root canals [12].

Previously our team has a rich experience in working on various research projects across multiple disciplines [13-27]. Now the growing trend in this area motivated us to pursue this project. The aim of the current review is to analyse and discuss the intracanal medicaments available and studied around the globe.

\section{Ideal Requirements Of Intracanal Medicaments} [28]

An ideal intracanal medicament should be an effective germicide and fungicide and have a prolonged antimicrobial effect. It should be non-irritating to periapical tissues in case of extrusion, remain stable in the form of solution, have low surface tension, not stain tooth structure, stay active in the presence of protein derivatives of tissues, blood and serum, not alter physiological activities of host tissues, not interfere with repair of periapical tissues and induce healing and hard tissue formation. It may contribute to reduce pain, control inflammatory root resorption, eliminate apical exudates and not alter the physiologic activities of the host tissues. Other properties like reasonable shelf life, availability and cost effectiveness also contribute to the selection of a suitable intracanal medicament.

\section{Factors Influencing Antiseptic Action (By Calvin D Torneck)}

Amongst the most important features of a root canal antiseptics is its ability to reduce the concentration of microbial flora in the root canal and whenever possible, its complete elimination. The antiseptic action of these drugs can be modified by several factors such as the drug itself, types of microorganisms, physical disposition of the bacteria and metabolic activity of the bacteria.

Drugs itself is the major factor. The antimicrobial effect of some drugs are better, extensive and more rapid than others. Another important feature is the mechanism of action which could be bacteriostatic or bactericidal. Bactericidal drugs are better in the long run. The root canal system inhabits a wide range of bacteria, hence the spectrum of action of these drugs must be wide. Combination of drugs, rotation or changing them is a strategy to have prolonged effect on polymicrobial infections. The concentration of the drug as well as the form in which it is available also extends an effect on the antimicrobial action. The drugs that are available in adequate concentrations and are available for a prolonged pe- riod are more effective than the ones the short lived ones. Also, the drugs that tend to disintegrate quickly and release the active component of the drug provide a better antimicrobial action.

The type, location, availability of nutrients and ability of species to survive, develop resistance and transmit the drug resistance all influence the efficacy of intracanal medicaments abundantly. It is essential for an intracanal medicament to be able to eliminate persister bacteria, microbial colonies residing deep with in and in inconspicuous areas like lateral canals, isthmus, irregular crevices. Residual necrotic tissue and wet canals contribute to the failure of complete disinfection.

The bacteria existing in the root canal systems are in the form of colonies or biofilms and hence their removal is more difficult than when compared in ideal in-vitro conditions. The antimicrobial agents which interfere with the metabolic activity of the bacteria almost instantly kill them and are more effective than others.

\section{Commonly Used Intracanal Medicaments}

\section{Phenol [28]}

Phenol is one of the oldest antiseptics introduced by Lord Lister into medicine in 1876. It is derived from coal tar or petroleum, is white in color and crystalline with a specific odour. Phenol has been used for sterilising dentin after cavity preparation, disinfection of root canals and to destroy pulpal remnants. Phenol's use as a disinfectant has been reduced because of its caustic nature, pungent aroma and inferior bacteriostatic action. Parachlorophenol, metacresylacetate and cresol are derived from it. The mechanism of action by which phenol acts as an antimicrobial is by its ability to disrupt and penetrate the cell wall of bacteria and subsequently precipitate protoplasmic protein. In lower concentrations it inactivates essential enzyme systems that cause cell death.

\section{Eugenol [28]}

Eugenol is an essential oil but chemically is related to phenolic compounds. In low concentrations, it has anodyne effect. It is a more effective antiseptic and less irritating than phenol and has hemolytic action. It is used as temporary dressings and antiseptic dressings following pulpectomy as it increases the microhardness of dentin and controls neural conduction. It has a wide range of action and is bacteriostatic in nature.

\section{Formaldehyde [6]}

It is a $37 \%$ solution of formaldehyde gas with a stabilizer like menthol $(8-15 \%)$ to reduce release of formaldehyde in the form of polymers. It cannot be refrigerated. Formaldehyde can be placed in the pulp chamber or in the cervical third of the root canal space and it is effective in the apical portion when the canal is reasonably clean and dry. Rapid necrosis of pulp tissue has been reported by the use of formaldehyde and hence it is used for fixing of the pulp tissue [29].

\section{Chlorhexidine}

It is a cationic bisguanide with low toxicity to periapical tissues and good antimicrobial efficacy against a broad range of micro- 
organisms. The active agent stays in contact with the canal wall and dentinal tubules due to low viscosity [30]. CHX adsorbs in to the cell wall of microorganisms and causes leakage of intracellular components. At lower concentrations, it is bacteriostatic causing intracytoplasmic contents to leak out while it is bactericidal at higher concentrations due to precipitation and coagulation of cytoplasm [31]. The combination of $\mathrm{CHX}$ and calcium hydroxide inhibits complete growth of E. faecalis after 24-48 hours with tapered decline over a week which can be attributed to the high $\mathrm{pH}$ of the combination product. CHX is an extremely efficient antimicrobial agent.

\section{Calcium Hydroxide [5, 32]}

Hermann introduced calcium hydroxide in 1920 as Calxyl. It has been put to use for managing root fractures, perforations, resorptions, traumatic injuries, etc. It is a white odourless powder with the formula $\mathrm{Ca}(\mathrm{OH}) 2$, a high $\mathrm{pH}$ of 12 to 12.8 and a molecular weight of 73.08. It induces deposition and mineralisation of hard tissues as the high $\mathrm{pH}$ activates the alkaline phosphatase activity. The antimicrobial action is dependent on the release of hydroxyl ions which damage the bacterial cytoplasmic membrane resulting in destruction of phospholipid structure of cell membrane, denatures proteins and adsorbs carbon dioxide disturbing the root canal ecosystem. Three types of vehicles namely aqueous, viscous and oily vehicles are used to deliver calcium hydroxide to root canals. The various aqueous vehicles used are sterile water, distilled water, bidistilled water, sterile saline, anaesthetic solutions, Ringer's solution, methylcellulose, carboxymethylcellulose. The various viscous vehicles used are glycerine, polyethylene glycol, propylene glycol. The various oily vehicles are olive oil, fatty acids, camphorated parachlorophenol, metacresylacetate, eugenol. The vehicles which prolong the action of calcium hydroxide and have a synergistic effect are chosen as vehicles for delivering this extremely effective medicament.

\section{Antibiotics [33]}

Certain selected antibiotics have been reportedly used as a root canal antiseptic. These are active in the presence of tissue fluid, do not stain the tooth and are virtually non-irritant to tissue cells along with being antimicrobial. Triple antibiotic paste (TAP) contains both bactericidal (metronidazole, ciprofloxacin) and bacteriostatic (minocycline) agents to allow for successful resolution of periapical infection [34]. The concern of triple antibiotic paste is that minocycline may cause tooth discoloration, hence DAP is used [35]. Another antibiotic paste PBSC consisting of penicillin, bacitracin, streptomycin and caprylate has been widely used. Another combination where nystatin has replaced sodium caprylate named as PBSN has also been used.

\section{Ledermix [36]}

It is a glucocorticoid antibiotic compound containing triamcinolone acetonide and demeclocycline at concentrations of $1 \%$ and $3.21 \%$ respectively.

\section{Natural Intracanal Medicaments}

\section{Propolis}

Propolis has a complex composition. It has active constituents like flavonoids, phenolics and aromatics. Propolis has a very wide range of biologic activities including antimicrobial, anti-inflammatory, antioxidant, anaesthetic, and cytotoxic properties. Propolis has significant antibacterial efficacy and can be used as an intracanal medicament $[37,38]$.

\section{Azadirachta Indica}

Commonly known as neem. Has an excellent and wide range of antimicrobial activity. The most important active constituents that contribute to the wide range of antimicrobial activity are azadirachtin, nimbolinin, nimbin, nimbidin. Neem has been tested for its antibacterial and antifungal activities in dentistry. Intracanal medicaments and irrigants that contained neem have been tried and tested over time [39-41].

\section{Arctium Lappa}

Arctium lappa is a plant obtained in japan and acclimated in Brazil. It has been widely used in medicine as it possesses significant antibacterial, antioxidant and antifungal properties. The antibacterial activity has been attributed to the presence of polyacetylonenes. Great antimicrobial potential by arctium lappa against root canal microbes has been observed [42].

\section{Eucalyptus Oil}

It is an essential oil, obtained from the leaf of Eucalyptus with

Figure 1. Sequelae of pulpitis [71].

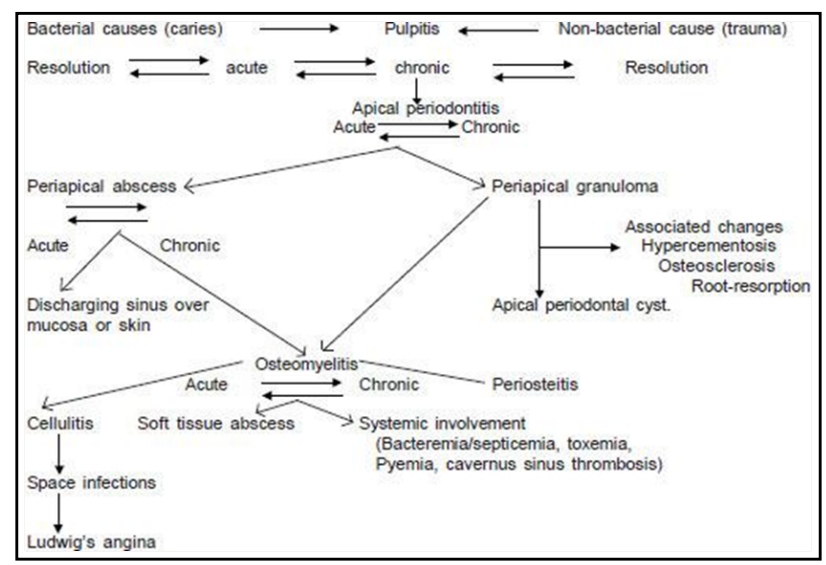


anti-inflammatory and antibacterial activities. It has a wide spectrum of antimicrobial action [43] and its potential use as a vehicle for calcium hydroxide has indicated towards its use as being an effective intracanal medicament.

\section{Ricinus Communis}

It is rich in ricinoleic acid (castor acid) and can be used as a root canal irrigant as well as an intracanal medicament [44].

\section{Uncaria Tomentosa}

An Amazonian herb possessing anti-inflammatory, antiviral, antibacterial, and antioxidant activities. It consists of oxindole alkaloids, triterpenes, vegetal steroids, phenolic compounds, glycosides, tannin and flavonoids which contribute to its antimicrobial activity. In dentistry, it can be used as an intracanal medicament [45].

\section{Casearia Sylvestris}

It is a medicinal plant found in tropical America and Brazil with antiseptic and antimicrobial activity. Casearia sylvestris can become a valid alternative for a short term intracanal medicament in cases of pulp and periapical inflammatory processes [46].

\section{Curcuma Longa}

Commonly known as turmeric. It exhibits good antioxidant, antimicrobial and anticancer activity with curcumin as an active ingredient. Curcuma longa can be used as an intracanal medicament as reported by Kumar et al 2013 [47].

\section{Morinda Citrifolia}

Widely known as Indian mulberry. It possesses a wide range of uses given its antibacterial, antiviral, anti-inflammatory, antioxidant and analgesic properties. Morinda citrifolia exhibits a good inhibition zone against E. Faecalis and hence can be used as an efficient intracanal medicament $[38,48]$.

\section{Papain}

Papain is a proteolytic cysteine enzyme with significant antibacterial and anti-inflammatory properties. It can be used as an intracanal medicament $[48,49]$.

\section{Ocimum Sanctum}

Widely known as Tulsi, it belongs to the Labiateae family and exhibits antibacterial, antifungal and antiviral properties. Ocimum sanctum's essential oil extract has excellent antibacterial effect [41, 50] which increases with increase in concentration.

\section{Allium Sativum}

Also known as Garlic. It has a broad spectrum of antimicrobial properties with both bacteriostatic and bactericidal activities. The antimicrobial potency is due to its ability to inhibit toxin production and expression of enzymes for pathogenesis. It could be an alternative intracanal medicament [51].

\section{Lemon Solution}

Lemon solution is a natural source of citric acid with low acidity. Fresh lemon solution was shown to have wide antibacterial efficacy including against E. Faecalis and hence can be used as an intracanal medicament [52].

\section{Cumimum Cynimum}

Commonly known as cumin, it has been reported to have excellent antioxidant, antibacterial, antifungal and analgesic properties. Activity against E. Faecalis tested and presents with good biocompatibility, effective to be used as an intracanal medicament $[53,54]$.

\section{Aloe Vera}

Aloe vera belongs to the liliaceae family. Medicinal products are made from the mucilaginous tissue in the centre of the aloe vera leaf and is called aloe vera gel. Total leaf extracts contain anthraquinones, which have antibacterial properties. Aloe vera has also been evaluated for its antibacterial efficacy and tested as an intracanal medicament $[48,55]$.

\section{Glycyrrhiza glabra [56]}

Liquorice is known for anti-inflammatory, antiviral and anticarcinogenic properties. Among various active ingredients is Glycyrrhizin, a triterpenoid compound which is active against different strains of S. Mutans. It has greater biocompatibility when compared to calcium hydroxide.

\section{Triphala (Haritaki, Bibhitaki and Amalaki)}

Triphala; a famous ayurvedic formulation has been proven to effectively inhibit biofilm. Can be tried as an intracanal medicament [57].

\section{Syzigium Aromaticum}

Available as an essential oil with antibacterial, antioxidant and anodyne properties [58].

\section{Foeniculum Vulgare}

Commonly called as fennel seed, belonging to the family of family A piaceas with reported antimicrobial, anti-inflammatory, analgesic, antispasmodic, antioxidant, diuretic, carminative and anti-cancer properties. In-vitro analysis suggested its use as an intracanal medicament [59]. Our institution is passionate about high quality evidence based research and has excelled in various fields [60-70].

\section{Conclusion}

Intracanal medications' contribution to the disinfection of the canal space is immense. The microbial load reduction by the combined use of irrigants and medicaments influences the treatment outcome. To choose an appropriate medicament, one has to analyse the properties, pros and cons. Most natural products are easily available and have good antimicrobial properties, but their efficiency in clinical setup needs to be evaluated. 


\section{References}

[1]. KAKEHASHI S, STANLEY HR, FITZGERALD RJ. THE EFFECTS OF SURGICAL EXPOSURES OF DENTAL PULPS IN GERM-FREE AND CONVENTIONAL LABORATORY RATS. Oral Surg Oral Med Oral Pathol. 1965 Sep;20:340-9. Pubmed PMID: 14342926.

[2]. Sundqvist G. Associations between microbial species in dental root canal infections. Oral Microbiol Immunol. 1992 Oct;7(5):257-62. Pubmed PMID: 1494447.

[3]. Hargreaves KM. Cohen's Pathways of the Pulp Expert Consult. 10th.

[4]. Tabassum S, Khan FR. Failure of endodontic treatment: The usual suspects. Eur J Dent. 2016 Jan-Mar;10(1):144-147. Pubmed PMID: 27011754.

[5]. Farhad A, Mohammadi Z. Calcium hydroxide: a review. Int Dent J. 2005 Oct;55(5):293-301. Pubmed PMID: 16245464

[6]. Chong BS, Pitt Ford TR. The role of intracanal medication in root canal treatment. Int Endod J. 1992 Mar;25(2):97-106. Pubmed PMID: 1399059.

[7]. Gomes BPFA, Herrera DR. Etiologic role of root canal infection in apical periodontitis and its relationship with clinical symptomatology. Braz Oral Res. 2018 Oct 18;32(suppl 1):e69. Pubmed PMID: 30365610.

[8]. Peters LB, Wesselink PR, Buijs JF, van Winkelhoff AJ. Viable bacteria in root dentinal tubules of teeth with apical periodontitis. J Endod. 2001 Feb;27(2):76-81. Pubmed PMID: 11491642.

[9]. Love RM, Jenkinson HF. Invasion of dentinal tubules by oral bacteria. Crit Rev Oral Biol Med. 2002;13(2):171-83. Pubmed PMID: 12097359.

[10]. Orstavik D. Intracanal medication. Harty's Endodontics in Clinical Practice, 4th edn. Oxford, UK: Wright. 1997:113.

[11]. Narayanan LL, Vaishnavi C. Endodontic microbiology. Journal of conservative dentistry: JCD. 2010 Oct;13(4):233.

[12]. Gomes BP, Lilley JD, Drucker DB. Clinical significance of dental root canal microflora. J Dent. 1996 Jan-Mar;24(1-2):47-55. Pubmed PMID: 8636492.

[13]. Govindaraju L, Gurunathan D. Effectiveness of Chewable Tooth Brush in Children-A Prospective Clinical Study. J Clin Diagn Res. 2017 Mar;11(3):ZC31-ZC34. Pubmed PMID: 28511505.

[14]. Christabel A, Anantanarayanan P, Subash P, Soh CL, Ramanathan M, Muthusekhar MR, et al. Comparison of pterygomaxillary dysjunction with tuberosity separation in isolated Le Fort I osteotomies: a prospective, multi-centre, triple-blind, randomized controlled trial. Int J Oral Maxillofac Surg. 2016 Feb;45(2):180-5. Pubmed PMID: 26338075.

[15]. Soh CL, Narayanan V. Quality of life assessment in patients with dentofacial deformity undergoing orthognathic surgery--a systematic review. Int J Oral Maxillofac Surg. 2013 Aug;42(8):974-80. Pubmed PMID: 23702370.

[16]. Mehta M, Deeksha, Tewari D, Gupta G, Awasthi R, Singh H, et al. Oligonucleotide therapy: An emerging focus area for drug delivery in chronic inflammatory respiratory diseases. Chem Biol Interact. 2019 Aug 1;308:206215. Pubmed PMID: 31136735.

[17]. Ezhilarasan D, Apoorva VS, Ashok Vardhan N. Syzygium cumini extract induced reactive oxygen species-mediated apoptosis in human oral squamous carcinoma cells. J Oral Pathol Med. 2019 Feb;48(2):115-121. Pubmed PMID: 30451321

[18]. Campeau PM, Kasperaviciute D, Lu JT, Burrage LC, Kim C, Hori M, et al. The genetic basis of DOORS syndrome: an exome-sequencing study. Lancet Neurol. 2014 Jan;13(1):44-58. Pubmed PMID: 24291220

[19]. Kumar S, Sneha S. Knowledge and awareness regarding antibiotic prophylaxis for infective endocarditis among undergraduate dental students. Asian Journal of Pharmaceutical and Clinical Research. 2016;154

[20]. Christabel SL, Gurunathan D. Prevalence of type of frenal attachment and morphology of frenum in children, Chennai, Tamil Nadu. World J Dent. 2015 Oct;6(4):203-7.

[21]. Kumar S, Rahman RE. Knowledge, awareness, and practices regarding biomedical waste management among undergraduate dental students. Asian Journal of Pharmaceutical and Clinical Research. 2017;10(8):341

[22]. Sridharan G, Ramani P, Patankar S. Serum metabolomics in oral leukoplakia and oral squamous cell carcinoma. J Cancer Res Ther. 2017 JulSep;13(3):556-561. Pubmed PMID: 28862226.

[23]. Ramesh A, Varghese SS, Doraiswamy JN, Malaiappan S. Herbs as an antioxidant arsenal for periodontal diseases. J Intercult Ethnopharmacol. 2016 Jan 27;5(1):92-6. Pubmed PMID: 27069730.

[24]. Thamaraiselvan M, Elavarasu S, Thangakumaran S, Gadagi JS, Arthie T. Comparative clinical evaluation of coronally advanced flap with or without platelet rich fibrin membrane in the treatment of isolated gingival recession. J Indian Soc Periodontol. 2015 Jan-Feb;19(1):66-71. Pubmed PMID: 25810596

[25]. Thangaraj SV, Shyamsundar V, Krishnamurthy A, Ramani P, Ganesan K, Muthuswami M, et al. Molecular Portrait of Oral Tongue Squamous Cell Carcinoma Shown by Integrative Meta-Analysis of Expression Profiles with
Validations. PLoS One. 2016 Jun 9;11(6):e0156582. Pubmed PMID: 27280700.

[26]. Ponnulakshmi R, Shyamaladevi B, Vijayalakshmi P, Selvaraj J. In silico and in vivo analysis to identify the antidiabetic activity of beta sitosterol in adipose tissue of high fat diet and sucrose induced type- 2 diabetic experimental rats. Toxicol Mech Methods. 2019 May;29(4):276-290. Pubmed PMID: 30461321.

[27]. Ramakrishnan M, Bhurki M. Fluoride, Fluoridated Toothpaste Efficacy And Its Safety In Children-Review. International Journal of Pharmaceutical Research. 2018 Oct 1;10(04):109-14.

[28]. Grossman LI. Endodontic practice, ed 10. Vol. 8, Journal of Endodontics. 1982;p. S34-5.

[29]. Cambruzzi JV, Greenfeld RS. Necrosis of crestal bone related to the use of excessive formocresol medication during endodontic treatment. J Endod. 1983 Dec;9(12):565-7. Pubmed PMID: 6581262.

[30]. Rosenthal S, Spångberg L, Safavi K. Chlorhexidine substantivity in root canal dentin. Oral Surg Oral Med Oral Pathol Oral Radiol Endod. 2004 Oct;98(4):488-92. Pubmed PMID: 15472666.

[31]. Gomes BP, Vianna ME, Zaia AA, Almeida JF, Souza-Filho FJ, Ferraz CC. Chlorhexidine in endodontics. Braz Dent J. 2013;24(2):89-102. Pubmed PMID: 23780357.

[32]. Mohammadi Z, Dummer PM. Properties and applications of calcium hydroxide in endodontics and dental traumatology. Int Endod J. 2011 Aug;44(8):697-730. Pubmed PMID: 21535021.

[33]. Mohammadi Z. Antibiotics as intracanal medicaments: a review. J Calif Dent Assoc. 2009 Feb;37(2):98-108. Pubmed PMID: 19489526.

[34]. Parhizkar A, Nojehdehian H, Asgary S. Triple antibiotic paste: momentous roles and applications in endodontics: a review. Restor Dent Endod. 2018 Jun 20;43(3):e28. Pubmed PMID: 30135847

[35]. Makandar SD, Noorani TY. Triple antibiotic paste-Challenging intracanal medicament: A systematic review. Journal of International Oral Health. 2020 May 1;12(3):189.

[36]. Murvindran V, Raj JD. Antibiotics as an intracanal medicament in endodontics. Journal of Pharmaceutical Sciences and Research. 2014 Sep 1;6(9):297.

[37]. Parolia A, Thomas MS, Kundabala M, Mohan M. Propolis and its potential uses in oral health. International Journal of Medicine and Medical Science. 2010;2(7):210-5.

[38]. Madhubala MM, Srinivasan N, Ahamed S. Comparative evaluation of propolis and triantibiotic mixture as an intracanal medicament against Enterococcus faecalis. J Endod. 2011 Sep;37(9):1287-9. Pubmed PMID: 21846550.

[39]. Babaji P, Jagtap K, Lau H, Bansal N, Thajuraj S, Sondhi P. Comparative evaluation of antimicrobial effect of herbal root canal irrigants (Morinda citrifolia, Azadirachta indica, Aloe vera) with sodium hypochlorite: An in vitro study. J Int Soc Prev Community Dent. 2016 May-Jun;6(3):196-9. Pubmed PMID: 27382533

[40]. Kusuma CS, Manjunath V, Gehlot PM. Comparative Evaluation of Neem, Aloevera, Chlorhexidine and Calcium Hydroxide as an Intracanal Medicament against E. faecalis-An in vitro Study. Journal of Clinical \& Diagnostic Research. 2018 Mar 1;12(3).

[41]. Mistry KS, Sanghvi Z, Parmar G, Shah S. The antimicrobial activity of Azadirachta indica, Mimusops elengi, Tinospora cardifolia, Ocimum sanctum and $2 \%$ chlorhexidine gluconate on common endodontic pathogens: An in vitro study. Eur J Dent. 2014 Apr;8(2):172-177. Pubmed PMID: 24966766.

[42]. Pereira JV, Bergamo DC, Pereira JO, França Sde C, Pietro RC, SilvaSousa YT. Antimicrobial activity of Arctium lappa constituents against microorganisms commonly found in endodontic infections. Braz Dent J. 2005;16(3):192-6. Pubmed PMID: 16429183.

[43]. Sivakumar A, Ravi V, Prasad AS, Sivakumar JS. Herbendodontics-Phytotherapy in endodontics: A review. Biomedical and Pharmacology Journal. 2018 Jun 25;11(2):1073-82.

[44]. Garcia LD, De Almeida GL, da CP Pires-de-Souza F, Consani S. Antimicrobial activity of a calcium hydroxide and Ricinus communis oil paste against microorganisms commonly found in endodontic infections. Revista Odonto Ciência. 2009 Jul 17;24(4):406-9.

[45]. Herrera DR, Tay LY, Rezende EC, Kozlowski VA Jr, Santos EB. In vitro antimicrobial activity of phytotherapic Uncaria tomentosa against endodontic pathogens. J Oral Sci. 2010 Sep;52(3):473-6. Pubmed PMID: 20881342.

[46]. Silva FB, Almeida JM, Sousa SM. Natural medicaments in endodontics a comparative study of the anti-inflammatory action. Braz Oral Res. 2004 Apr-Jun;18(2):174-9. Pubmed PMID: 15311323.

[47]. Kumar H. An in vitro evaluation of the antimicrobial efficacy of Curcuma longa, Tachyspermum ammi, chlorhexidine gluconate, and calcium hydroxide on Enterococcus faecalis. J Conserv Dent. 2013 Mar;16(2):144-7. Pubmed PMID: 23716967.

[48]. Bhardwaj A, Ballal S, Velmurugan N. Comparative evaluation of the antimicrobial activity of natural extracts of Morinda citrifolia, papain and aloe 
vera (all in gel formulation), 2\% chlorhexidine gel and calcium hydroxide, against Enterococcus faecalis: An in vitro study. J Conserv Dent. 2012 Jul;15(3):293-7. Pubmed PMID: 22876022

[49]. Kishan KV, Shah N, Naveen M. Use of natural substitutes as an intracanal medicament in the endodontics-An update for in vivo studies. Indian Journal of Natural Products and Resources (IJNPR)[Formerly Natural Product Radiance (NPR)]. 2020 Sep 24;11(3):165-8.

[50]. Ahirwar P, Shashikiran ND, Sundarraj RK, Singhla S, Thakur RA, Maran S. A clinical trial comparing antimicrobial efficacy of "essential oil of Ocimum sanctum" with triple antibiotic paste as an intracanal medicament in primary molars. J Indian Soc Pedod Prev Dent. 2018 Apr-Jun;36(2):191-197. Pubmed PMID: 29970638.

[51]. Satvati SA, Shooriabi M, Amin M, Shiezadeh F. Evaluation of the Antimicrobial activity of Tribulus terrestris, Allium sativum, Salvia officinalis, and Allium hirtifolium Boiss against Enterococcus faecalis. International Journal of Enteric Pathogens. 2017 May 21;5(2):63-7.

[52]. Varshini R, Subha A, Prabhakar V, Mathini P, Narayanan S, Minu K. Antimicrobial Efficacy of Aloe vera, Lemon, Ricinus communis, and Calcium Hydroxide as Intracanal Medicament Against Enterococcus faecalis: A Confocal Microscopic Study. J Pharm Bioallied Sci. 2019 May;11(Suppl 2):S256-S259. Pubmed PMID: 31198348.

[53]. Abbaszadegan A, Gholami A, Ghahramani Y, Ghareghan R, Ghareghan M, Kazemi A, et al. Antimicrobial and Cytotoxic Activity of Cuminum Cyminum as an Intracanal Medicament Compared to Chlorhexidine Gel. Iran Endod J. 2016 Winter;11(1):44-50. Pubmed PMID: 26843877.

[54]. Abbaszadegan A, Dadolahi S, Gholami A, Moein MR, Hamedani S, Ghasemi Y, et al. Antimicrobial and Cytotoxic Activity of Cinnamomum zeylanicum, Calcium Hydroxide, and Triple Antibiotic Paste as Root Canal Dressing Materials. J Contemp Dent Pract. 2016 Feb 1;17(2):105-13. Pubmed PMID: 27206997.

[55]. Kurian B, Swapna DV, Nadig RR, Ranjini MA, Rashmi K, Bolar SR. Efficacy of calcium hydroxide, mushroom, and Aloe vera as an intracanal medicament against Enterococcus faecalis: An in vitro study. Endodontology. 2016 Jul 1;28(2):137.

[56]. Sidhu P, Shankargouda S, Rath A, Hesarghatta Ramamurthy P, Fernandes B, et al. Therapeutic benefits of liquorice in dentistry. J Ayurveda Integr Med. 2020 Jan-Mar;11(1):82-88. Pubmed PMID: 30391123.

[57]. Marickar RF, Geetha RV, Neelakantan P. Efficacy of contemporary and novel Intracanal medicaments against enterococcus faecalis. J Clin Pediatr Dent. 2014 Fall;39(1):47-50. Pubmed PMID: 25631726

[58]. Sinha DJ, Sinha AA. Natural medicaments in dentistry. Ayu. 2014 Apr;35(2):113-8. Pubmed PMID: 25558153.

[59]. HEMMANUR S, NASIM I. EVALUATION OF ANTIMICROBIAL EFFICACY OF Foeniculum vulgare ESSENTIAL OIL-AN in vitro STUDY. PLANT CELL BIOTECHNOLOGY AND MOLECULAR BIOLOGY. 2020 Aug 24:83-9.
[60]. Vijayashree Priyadharsini J. In silico validation of the non-antibiotic drugs acetaminophen and ibuprofen as antibacterial agents against red complex pathogens. J Periodontol. 2019 Dec;90(12):1441-1448. Pubmed PMID: 31257588.

[61]. J PC, Marimuthu T, C K, Devadoss P, Kumar SM. Prevalence and measurement of anterior loop of the mandibular canal using CBCT: A cross sectional study. Clin Implant Dent Relat Res. 2018 Aug;20(4):531-534. Pubmed PMID: 29624863.

[62]. Ramesh A, Varghese S, Jayakumar ND, Malaiappan S. Comparative estimation of sulfiredoxin levels between chronic periodontitis and healthy patients - A case-control study. J Periodontol. 2018 Oct;89(10):1241-1248. Pubmed PMID: 30044495.

[63]. Ramadurai N, Gurunathan D, Samuel AV, Subramanian E, Rodrigues SJL. Effectiveness of $2 \%$ Articaine as an anesthetic agent in children: randomized controlled trial. Clin Oral Investig. 2019 Sep;23(9):3543-3550. Pubmed PMID: 30552590.

[64]. Sridharan G, Ramani P, Patankar S, Vijayaraghavan R. Evaluation of salivary metabolomics in oral leukoplakia and oral squamous cell carcinoma. J Oral Pathol Med. 2019 Apr;48(4):299-306. Pubmed PMID: 30714209.

[65]. Ezhilarasan D, Apoorva VS, Ashok Vardhan N. Syzygium cumini extract induced reactive oxygen species-mediated apoptosis in human oral squamous carcinoma cells. J Oral Pathol Med. 2019 Feb;48(2):115-121. Pubmed PMID: 30451321.

[66]. Mathew MG, Samuel SR, Soni AJ, Roopa KB. Evaluation of adhesion of Streptococcus mutans, plaque accumulation on zirconia and stainless steel crowns, and surrounding gingival inflammation in primary molars: randomized controlled trial. Clin Oral Investig. 2020 Sep;24(9):3275-3280. Pubmed PMID: 31955271.

[67]. Samuel SR. Can 5-year-olds sensibly self-report the impact of developmental enamel defects on their quality of life? Int J Paediatr Dent. 2021 Mar;31(2):285-286. Pubmed PMID: 32416620.

[68]. R H, Ramani P, Ramanathan A, R JM, S G, Ramasubramanian A, et al. CYP2 C9 polymorphism among patients with oral squamous cell carcinoma and its role in altering the metabolism of benzo[a]pyrene. Oral Surg Oral Med Oral Pathol Oral Radiol. 2020 Sep;130(3):306-312. Pubmed PMID: 32773350 .

[69]. Chandrasekar R, Chandrasekhar S, Sundari KKS, Ravi P. Development and validation of a formula for objective assessment of cervical vertebral bone age. Prog Orthod. 2020 Oct 12;21(1):38. Pubmed PMID: 33043408.

[70]. Vijayashree Priyadharsini J, Smiline Girija AS, Paramasivam A. In silico analysis of virulence genes in an emerging dental pathogen A. baumannii and related species. Arch Oral Biol. 2018 Oct;94:93-98. Pubmed PMID: 30015217.

[71]. Sureshchandra B. Gopikrishna V. Grossman's endodontic practice. 13th Edition. Ser, editor. India: Wolter Kluwer Health. 2014:343. 